\title{
Sisävesien fosforikuormitus Kirmanjärven valuma-alueella Pohjois-Savossa
}

\author{
Mari Räty $^{1)}$, Perttu Virkajärvi ${ }^{1)}$, Kirsi Saarijärvi ${ }^{1)}$, Erkki Saarijärvi ${ }^{2)}$ ja Helinä Hartikainen ${ }^{4)}$ \\ ${ }^{1)}$ Maa- ja elintarviketalouden tutkimuskeskus MTT, Kotieläintuotannon tutkimus, Halolantie 31 A, \\ 71750 Maaninka,mari.raty@mtt.fi,perttu.virkajarvi@mtt.fi,kirsi.saarijarvi@mtt.fi \\ ${ }^{2)}$ Vesi-Eko Oy Water-Eco Ltd, Yrittäjäntie 12, 70150 Kuopio, erkki.saarijarvi@vesieko.fi \\ ${ }^{3)}$ Elintarvike- ja ympäristötieteiden laitos, PL 27, Latokartanonkaari 11, 00014 Helsingin yliopisto, \\ helina.hartikainen@helsinki.fi
}

\section{Tiivistelmä}

Suomen peltoalasta kolmannes eli yli 620000 hehtaaria on nurmia ja suurin osa nurmiviljelystä on keskittynyt Savoon sekä Pohjanmaalle. Intensiivisen karjanlantaan perustuvan nurmiviljelyn aiheuttama fosforikuormitus on pintavesien laadun kannalta vakava ongelma, mikä näkyy heikentyneenä veden laatuna erityisesti Pohjois-Savon järvialueella ja Pohjanmaan jokivesistöjen alueella. Nurmiviljelyssä eroosio on tunnetusti vähäistä ja valtaosa pintavalunnan fosforikuormituksesta on liukoisessa muodossa, kuormituksen ollessa selvästi kevätpainotteista. Nurmivuosina pintaan annettu fosforilannoitus ja pintaan levitettävä lietelanta johtavat maan fosforipitoisuuden nousuun ja sitä kautta pintavalunnan fosforipitoisuuden kasvuun. Koska nurmilta tuleva fosforikuormitus on luonteeltaan erilaista kuin Etelä-Suomen savisilla vilja-alueilla, eivät siellä kehitetyt mallit ja kuormituksen vähentämiskeinot sovellu Nurmi-Suomen alueelle. Tämän tutkimuksen tavoitteena on mitata valumaa ja kuormitusta kolmen hydrologisen vuoden ajan (2011-14) ja selvittää luotettavasti nurmiviljelyalueelta tulevan vesistökuormituksen määrä ja dynamiikka pienen valuma-aluetason mittakaavassa.

Vuonna 2010 sijoitettiin nurmi- ja lumi-Suomen alueelle Ylä-Savoon Kirmanjärvelle valumaaluetason automaattinen ja jatkuvatoiminen ravinnekuormituksen seurantalaitteisto. Alueen $\left(3,0 \mathrm{~km}^{2}\right)$ peltoprosentti on 32. Seuranta-alueet, joiden ojissa mittauspisteet sijaitsevat, vaihtelevat maankäytöltään peltovaltaisesta (pelto-\% 100) metsävaltaiseen (metsä-\% lähes 100). Ravinnekuormituksen seurantalaitteisto koostuu sääasemasta ja viidestä eri mittauspisteestä, joista jokainen sisältää ohjelmoitavan näytteenotto- ja virtaamamittauslaitteiston. Vesinäytteet otetaan virtaamapainotettuina kokoomanäytteinä ja niistä määritetään kokonaisfosfori, liukoinen fosfori, kiintoaines, kokonaistyppi, nitraattityppi, ammoniumtyppi, liukoinen orgaaninen hiili, liukoinen kalsium, $\mathrm{pH}$ ja sähkönjohtokyky. Tutkimuksessa on otettu näytteitä ja tehty virtaamamittauksia ensimmäisen havaintovuoden ajalta (syksy10-syksy-11).

Virtaama oli suurimmillaan kolme viikkoa kestävän lumen sulamisen aiheuttaman tulvahuipun aikana. Tämän takia kevätsulamisen aikaan tulevan fosforikuorman merkitys kokonaiskuormituksen kannalta on keskeinen. Alustavat tulokset osoittavat, että Kirmanjärveen laskevasta Ruostepurosta maa- ja metsätalousvaltaisen valuma-alueen pinta-alayksikköä kohti laskettu kokonaisfosforihuuhtouma jää kokonaisuutena suomalaisille peltovaltaisille alueille esitettyjä ominaiskuormitusarvioita huomattavastikin pienemmäksi, kun taas pienelle peltovaltaiselle (pelto-\% 100) seurantakohteelle laskettu ominaiskuormitusarvio vastaa kirjallisuudessa esitettyjä arvioita. Virtaama ja ravinnekuormitus vaihtelevat vuositasolla voimakkaasti, minkä vuoksi nurmialueilta tulevan kuormituksen luotettava arviointi on saavutettavissa ainoastaan riittävällä näytteenottotiheydellä ja monivuotisella seurantatutkimuksella.

Asiasanat: fosfori, hajakuormitus, nurmiviljely, talvi, sisävesistöt 


\section{Johdanto}

Hajakuormituksena vesistöihin kulkeutuva fosfori rasittaa sisämaan pintavesiä ja Itämerta, eikä kuormitus ole juurikaan vähentynyt viime vuosina (Ekholm ym. 2007). Sisävesien ja Pohjanmeren valumaalueet poikkeavat Suomenlahden ja Ahvenanmeren valuma-alueesta maalajien, ilmasto-olosuhteiden ja maatilojen tuotantorakenteen osalta. Samalla kun tuotannon alueellinen keskittyminen lisää ravinneylijäämiä, vaaditaan nopeasti maatalouden aiheuttaman vesistökuormituksen vähentämistä. Tämän ongelman ratkaiseminen on suuri haaste.

Suomen peltoalasta kolmannes eli yli 620000 hehtaaria on nurmia. Suurin osa nurmiviljelystä on keskittynyt Savoon sekä Etelä-, Keski- ja Pohjois-Pohjanmaalle (MMM TIKE 2007). Intensiiviseen karjanlannan käyttöön perustuvan nurmiviljelyn aiheuttama fosforikuormitus on pintavesien laadun kannalta vakava ongelma, mikä näkyy heikentyneenä veden laatuna erityisesti Pohjois-Savon järvialueella ja Pohjanmaan jokivesistöjen alueella. Pohjois-Savon vesistöjen ekologinen tila on valtaosiltaan vähintään hyvä, mutta tyydyttävän ja välttävän luokituksen vesien osuus on merkittävä etenkin Iisalmen reitillä. Alueelle on asetettu maatalouden osalta huomattavia kuormituksen vähentämistarpeita (Pohjois-Savon ELY-keskus 2010).

Nurmiviljelyssä eroosio on tunnetusti vähäistä. Valuma- ja lysimetrikentiltä saatujen mittaustulosten mukaan nurmilta huuhtoutuu fosforia $1-2 \mathrm{~kg} \mathrm{ha}^{-1} \mathrm{v}^{-1}$ pintavalunnan mukana, josta liukoisen, biologisesti välittömästi käyttökelpoisen fosforin osuus on jopa 80-95 \% ja partikkeleihin sitoutuneen fosforin osuus vastaavasti vain vähäinen (Turtola \& Kemppainen 1998, Saarijärvi ym. 2006). Nurmien viljely muokkaamatta kerryttää fosforia maan pintakerrokseen (Saarela \& Vuorinen 2009), mikä johtuu etenkin nurmivuosina pintaan annetusta fosforilannoituksesta ja pintaan levitettävästä lietelannasta. Pintamaan korkean fosforitason on osoitettu lisäävän valumaveden fosforipitoisuutta (Sharpley 1995, Turtola \& Yli-Halla 1999), ja siten kasvattavan kuormituspotentiaalia. Nurmiviljelyn fosforikuormituksen on havaittu olevan selvästi kevätpainotteista: MTT:n Maaningan lysimetrikentällä havaittiin, että $90 \%$ vuotuisesta pintavalunnan fosforikuormituksesta syntyi lumen sulamisjakson aikana sekä nurmivuosina että nurmen uusimisvuonna (julkaisematon aineisto). Ilmastonmuutoksen myötä leudot ja sateiset talvet tulevat yleistymään, mikä muuttaa valunnan ajallista jakautumista lisäten syysja talvikuukausien aikaista valuntaa ja siten myös fosforin huuhtoutumisriskiä talvikaudella.

Koska nurmilta tuleva fosforikuormitus on luonteeltaan erilaista kuin Etelä-Suomen savisilla vilja-alueilla, eivät siellä kehitetyt mallit ja kuormituksen vähentämiskeinot sovellu Nurmi-Suomen alueelle. Tällä hetkellä suositeltuja keinoja ovat kevennetty muokkaus, ravinnetaseet, karjanlannan käytön tehostaminen, talviaikaisen kasvipeitteisyyden lisääminen sekä suojavyöhykkeiden ja kosteikkojen perustaminen (Kotanen ym. 2010). Näistä kevennetty muokkaus, suojakaistat ja talviaikainen kasvipeitteisyys eivät sovellu nurmiviljelyn fosforikuormituksen vähentämiseksi. Tämän tutkimuksen tavoitteena on mitata valumaa ja kuormitusta kolmen hydrologisen vuoden ajan (2011-14) ja selvittää luotettavasti nurmiviljelyalueelta tulevan vesistökuormituksen määrä ja dynamiikka pienen valumaaluetason mittakaavassa. Etäisyyden tai kuviokoon vaikutusta huuhtoutuvien ravinteiden määrään ei olisi mahdollista mitata ilman tarkoitukseen sopivaa sijainniltaan eristynyttä peltoaluetta sekä jatkuvatoimista mittauslaitteistoa ja näytteenottomenetelmää. Kuormituksen määrä ja dynamiikka sekä sen muuttuminen ajan ja paikan funktiona on tunnettava, jotta kuormituksen eri vähentämiskeinojen käyttökelpoisuus nimenomaan nurmiviljelyssä voidaan selvittää ja siten vähentämiskeinot voidaan kohdentaa tehokkaasti.

\section{Aineisto ja menetelmät}

Vuonna 2010 hankittiin MTT:n ja MMM:n rahoittamassa hankkeessa nurmi- ja lumi-Suomen alueen valuma-aluetason automaattinen ja jatkuvatoiminen ravinnekuormituksen seurantalaitteisto ja se sijoitettiin Iisalmeen Pohjois-Savoon, Kirmanjärvelle Ruostepuron osavaluma-alueelle. Kirmanjärven koko valuma-alue on noin $27 \mathrm{~km}^{2}$, josta peltoa on $31 \%$ (Kauppinen 2006). Kirmanjärvi (pinta-ala $5 \mathrm{~km}^{2}$ ) toimii Ylä-Savon Vesi Oy:n varavesilähteenä ja tekopohjaveden raakavesilähteenä, ja sen ekologista tilaa heikentävät korkeat klorofyllipitoisuudet (Pohjois-Savon ELY-keskus 2010).

Koska nurmilta tuleva fosfori on pääosin liukoisessa muodossa eikä sen pitoisuutta voida epäsuorasti arvioida veden sameuden perusteella, hankittiin tarkoitukseen soveltuvat näytteenottolaitteet. Fosforikuormituksen seurantalaitteisto koostuu sääasemasta ja viidestä eri mittauspisteestä, joista jokainen sisältää ohjelmoitavan näytteenotto- (Liquiport 2000 RPT20) ja virtaamamittauslaitteiston. Näytteenottolaitteistot ja dataloggerit on sijoitettu tarkoitusta varten rakennettuihin ja tarvittaessa 
lämmitettäviin näytteenottokoppeihin. Kolmessa mittauspisteessä virtaama mitataan ultraäänilaitteella (Starflow Ultrasonic Doppler Instrument Model 6526) ja kahdessa mittauspisteessä veden virtausnopeus lasketaan paineantureilla (Argonaut-SW) saatavien vedenkorkeustietojen ja V-mittapadosta manuaalisesti mitattujen vedenkorkeustietojen avulla. Vesinäytteet otetaan virtaamapainotettuina kokoomanäytteinä, ja niistä määritetään kokonaisfosfori, liukoinen fosfori (suodatus: huokoskoko $0,2 \mu \mathrm{m}: n$ kalvosuodatin), kiintoaines, kokonaistyppi, nitraattityppi, ammoniumtyppi, liukoinen orgaaninen hiili, liukoinen kalsium, pH ja sähkönjohtokyky (MTT laboratorio, Jokioinen). Tutkimuksessa on otettu näytteitä ja tehty virtaamamittauksia ensimmäisen havaintovuoden ajalta (syksy-10-syksy-11).

Ruostepuron osavaluma-alueella $\left(3,0 \mathrm{~km}^{2}\right)$ maankäyttömuodot ovat: pelto-\% 32, metsä-\% 50 ja suo-\% 18 (Kauppinen 2006). Seuranta-alueet, joiden ojissa mittauspisteet sijaitsevat, vaihtelevat maankäytöltään peltovaltaisesta (Piste 4: pelto-\% n. 50 ja metsä-\% n. 50, n. 54 ha; Piste 3: pelto-\% 100, n. 30 ha) metsävaltaiseen (Piste 5: metsä-\% lähes 100, n. 93 ha) (Kuva 1). Viljelykasveina viljellään enimmäkseen rehunurmea ja -viljaa. Seuranta-alueella sijaitseva Sumppilampi (Piste 2) on ollut vesijättöalue, joka on vuonna 1995 rakennettu lintukosteikoksi. Kosteikon pinta-alan suhde sen yläpuolisen valuma-alueen pinta-alaan on noin 1,7\%. Mittalaiteverkoston mittauspisteistä kaksi sijaitsevat kosteikkoon laskevissa ojissa ja yksi on välittömästi kosteikon alapuolelle. Siten kosteikkoon tulevan ja sieltä lähtevän veden laatua ja määrää voidaan seurata.

Tulosten tulkinnan yhteydessä tullaan hyödyntämään tiloilta saatavia tietoja viljelymenetelmistä ja lohkojen viljavuusanalyysituloksista sekä Ruostepuron osavaluma-alueen ojista otettujen sedimenttinäytteiden analyysituloksia. Tavoitteena on myös arvioida maaperäanalyysien käyttökelpoisuutta huuhtoutumisriskin kuvaajana. Ylä-Savon vesistöt kuntoon -hankkeen aikana kerättiin vuosina 2005-2010 ympäristöarviointiin osallistuvilta yläsavolaisilta tiloilta maan viljavuustietoja. Keskimääräinen viljavuusfosforipitoisuus (hapan ammoniumasetaattiuutto; Vuorinen \& Mäkitie 1955) viljatiloilla oli $8,8 \mathrm{mg} \mathrm{P}^{-1}$ maata $(\mathrm{n}=44)$, nautatiloilla $10,8 \mathrm{mg} \mathrm{P}^{-1}$ maata $(\mathrm{n}=229)$ ja sikatiloilla $12,5 \mathrm{mg}$ $\mathrm{P}^{-1}$ maata $(\mathrm{n}=101)$. Keskiarvo oli $10,9 \mathrm{mg} \mathrm{P}^{-1}$ maata, mikä on alle koko Suomea vastaavan keskiarvon (Saarijärvi, K. 2011.; Ylä-Savon Vesistöt Kuntoon -hanke, Maatilojen ympäristöarviointi, Loppuraportti).

Ensimmäiset ojasedimenttinäytteet otettiin syksyllä 2010 yhdestätoista eri näytteenottopisteestä neljänä rinnakkaisena kolmesta syvyydestä $(0-2,5 ; 2,5-8 / 2,5-10 ; 8-15 / 10-20 \mathrm{~cm})$. Sedimenttinäytteet nro 1-8 edustavat pelto-ojanäytteitä (nro 5-6 Ruostepuron alajuoksua) ja näytteet nro 9-11 metsäojanäytteitä. Sedimenttiaineksen epäorgaanisen fosforin määrää tutkittiin modifioidulla Changin ja Jacksonin (1957) fraktiointimenetelmällä (Hartikainen 1979). Epäorgaanisen fosforin sitoutumismuotojen (fraktioiden) selvittämiseksi sedimenttiainesta (1,0 g ilmakuivaa maata) käsiteltiin perättäisillä uutoilla (1:50): 1) $\mathrm{NH}_{4}$ Cl-liuoksella $(1,0 \mathrm{M})$ uutetaan helppoliukoinen fosfori ja poistetaan vaihtuva kalsium, 2) $\mathrm{NH}_{4} \mathrm{~F}$-liuoksella $(0,5 \mathrm{M} ; \mathrm{pH} 8,5)$ uutetaan fraktio, jonka katsotaan edustavan $\mathrm{Al}$ oksihydroksidien sitomia varoja, 3) $\mathrm{NaOH}$-liuoksella $(0,1 \mathrm{M})$ uutetaan Fe-oksihydroksidien sitomat varat, ja 4) $\mathrm{H}_{2} \mathrm{SO}_{4}$-liuoksella $(0,25 \mathrm{M})$ uutetaan $\mathrm{Ca}$ :n sitoma apatiittinen fosfori. Al- ja $\mathrm{Fe}$-oksidien fosforinkyllästysasteiden $\left(\mathrm{NH}_{4} \mathrm{~F}-\mathrm{P} / \mathrm{Al}_{\mathrm{ox}} ; \mathrm{NaOH}-\mathrm{P} / \mathrm{Fe}_{\mathrm{ox}}\right)$ laskemiseksi ja sitoutumislujuuden arvioimiseksi sedimenttinäytteistä tullaan määrittämään pidättävien Al:n ja Fe:n heikosti kiteytyneiden oksidien määrä oksalaattiuutolla. 


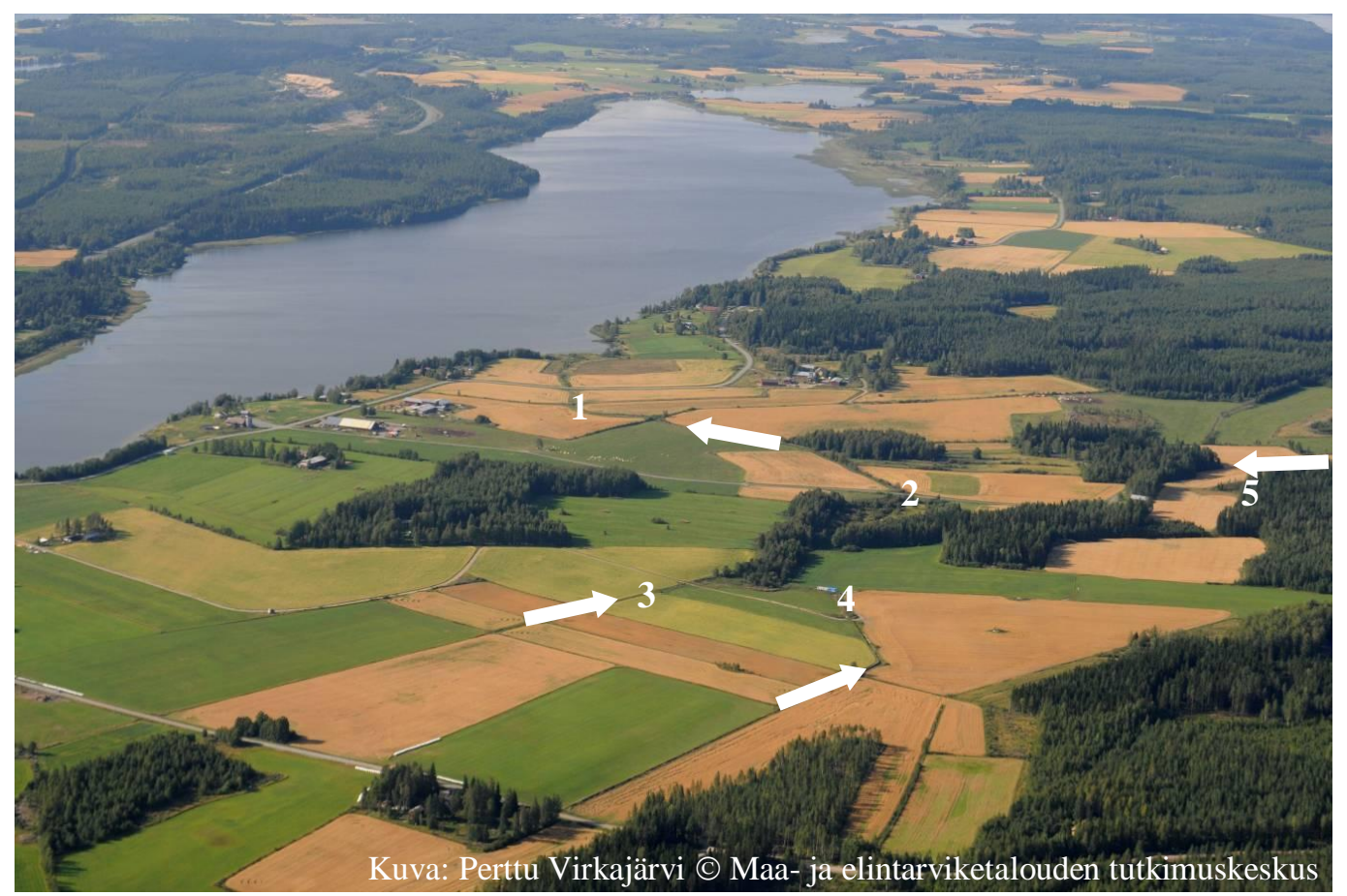

Kuva 1. Fosforikuormituksen seurantapisteet Kirmanjärven Ruostepuron osavaluma-alueella $\left(3,0 \mathrm{~km}^{2}\right)$. $1=\mathrm{Kir}-$ manjärveen laskevassa Ruostepurossa oleva mittauspiste, 2 = Sumppilammen kosteikon alapuolella oleva mittauspiste, 3 = peltovaltainen seuranta-alue (pelto- $\%$ 100), 4 = pelto- ja metsävaltainen seuranta-alue (pelto- $\% \mathrm{n}$. 50, metsä-\% n. 50) ja 5 = metsävaltainen seuranta-alue (metsä-\% lähes 100).

\section{Tulokset ja tulosten tarkastelu}

Sedimenttiaineksen fosforin fraktioinnin avulla pyrittiin arvioimaan ympäristöolosuhteiden vaihtelulle alttiin ja potentiaalisesti vapautumiskelpoisen fosforivaraston suuruutta. Fraktioiden summana lasketun epäorgaanisen fosforin kokonaismäärät vaihtelivat voimakkaasti $420-1180 \mathrm{mg} \mathrm{kg}^{-1}$ näytteenottopisteiden välillä (Kuva 2), mikä on samanlainen kuin Hartikaisen (1979) hyvin erityyppisille kivennäismaille saama vaihteluväli (160-1450 mg P kg-1). Pienimmät ja valtaosin mittaustarkkuuden alapuolella jääneet fosforimäärät olivat helppoliukoista fosforia edustavassa $\mathrm{NH}_{4} \mathrm{Cl}$-fraktiossa, suurimmat joko raudan sitomaksi oletetussa potentiaalisesti vapautumiskelpoisessa $\left(\mathrm{Fe}^{3+}: \mathrm{n}\right.$ pelkistyessä $\left.\mathrm{Fe}^{2+}: \mathrm{ksi}\right)$ $\mathrm{NaOH}$-fraktiossa (7-56\% fraktioiden summasta) tai vaikealiukoisessa $\mathrm{H}_{2} \mathrm{SO}_{4}$-liukoisessa fraktiossa (35-90 \% fraktioiden summasta). Apatiittisen, käytännössä biologisesti käyttökelvottoman fosforin suuri määrä kuvastaa maa-aineksen melko alhaista rapautumisastetta (Kaila 1964). Sekundaaristen fosfaattien huomattavasti suuremmat määrät pelto-ojasedimentissä metsäojasedimentteihin verrattuna selittyvät lannoitefosforin kertymisellä.

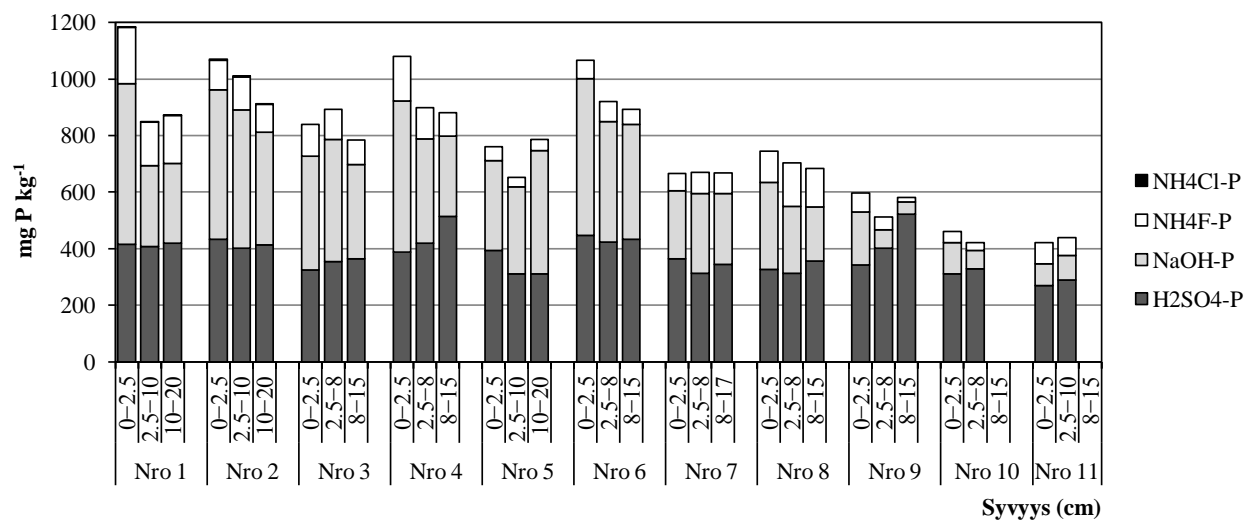

Kuva 2. Sedimenttiaineksen epäorgaanisen fosforin fraktiot $\left(\mathrm{mg} \mathrm{P} \mathrm{kg}^{-1}\right)$. Sedimenttinäytteet nro 1-8 edustavat pelto-ojanäytteitä (nro 5-6 Ruostepuron alajuoksua) ja näytteet nro 9-11 metsäojanäytteitä. 
Vuoden 2011 mittausjakso alkoi 5.4.2011 (päättyi 12.12.11). Sadesumma 1.1.-7.12.11 oli $701 \mathrm{~mm}$ (1.1.-31.5.; $183 \mathrm{~mm}$; 1.6.-31.8.; $312 \mathrm{~mm}, 1.9 .-7.12 . ; 206 \mathrm{~mm}$ ). Suurin vuorokausisadanta oli $37 \mathrm{~mm}$ (24.7.) (Vieremä, Kaarakkala; Ilmatieteen laitos, Ilmastokeskus, sähköposti 8.12.11). Ruostepuron osavaluma-alueella lumen paksuus oli maaliskuun lopussa keskimäärin $66 \mathrm{~cm}(56-76 \mathrm{~cm})$ vastaten $146 \mathrm{~kg} \mathrm{~m}^{-2}\left(112-186 \mathrm{~kg} \mathrm{~m}^{-2}\right)(\mathrm{n}=35)$. Lumipeite pysyi läpi talven 2011 ja se suli kerralla pois huhtikuussa. Lumen suuren määrän ja nopean sulamisen vuoksi sulannan alkuvaiheessa ojat tulvivat voimakkasti, ja sulamisvesi tulvi mittapatojen yli. Tästä johtuen paineantureihin ja mittapatoihin perustuva virtaama ei tulvahuipun aikana ollut kaikissa seurantapisteissä luotettavasti mitattavissa. Akustinen virtausmittari osoittautui käyttökelpoiseksi etenkin hankalien kevätvalumien olosuhteissa. Niitä hankittiin voimakkaasti tulvivan Sumppilammen seurantapisteeseen sekä toiseen peltovaltaisen seurantaalueen ojista.

Vuonna 2011 vesinäytteissä oli liukoista fosforia $0-1,23 \mathrm{mg} \mathrm{P}^{-1}$ ja kokonaisfosforia $0,01-1,46$

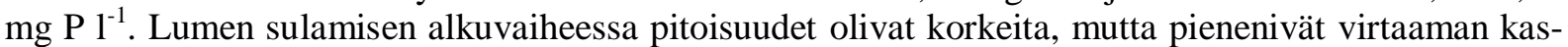
vaessa. Koska roudassa olevasta ja lumen peittämästä maasta eroosio on vähäistä, ja liukoisen fosforin osuus kokonaisfosforista oli suuri, korkeat pitoisuudet selittynevät pääosin fosforin vapautumisella kasvinjäänteistä. Kesän ja syksyn aikana pitoisuudet kohosivat fosforin konsentroituessa ojavesiin, joissa virtaamat olivat hyvin pieniä. Liukoinen fosfori muodosti $0-88 \%$ vesinäytteiden kokonaisfosforista (keskiarvo $45 \%$ ), mikä heijastui myös kiintoaine- ja kokonaisfosforipitoisuuden väliseen riippuvuussuhteeseen (Kuva 3). Kun aineistosta poistettiin näytteet, joiden korkea kiintoainespitoisuus oli selitettävissä näytteenottimen huuhteluprosessin yhteydessä pohja-aineksen joutumisella näytteeseen, ei kokonaisfosforipitoisuus korreloinut kiintoainespitoisuuden kanssa eikä sen pitoisuus siten olisi ollut laskettavissa sameuden perusteella. Siimekselä ym. (2011) ovat kuitenkin havainneet, että vaikka maa- ja metsätalousvaltaiselta valuma-alueelta tuleva fosforikuormitus oli pääosin liukoisessa muodossa, laboratoriossa vesinäytteistä määritetyn kokonaisfosforin ja automaattianturin mittaaman sameuden välillä oli merkittävä positiivinen korrelaatio.

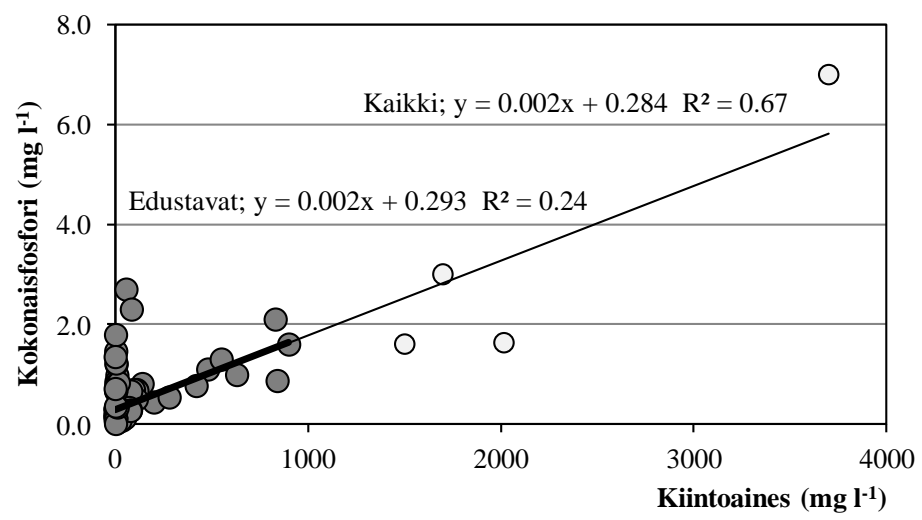

Kuva 3. Vesinäytteiden kiintoainespitoisuuden $\left(\mathrm{mg} \mathrm{l}^{-1}\right)$ ja kokonaisfosforipitoisuuden $\left(\mathrm{mg} \mathrm{l}^{-1}\right)$ välinen riippuvuus. $\quad \mathrm{O}=$ Edustavat näytteet; $\quad \mathrm{O}=$ Näytteet, joiden kiintoainespitoisuus on arveluttavan korkea.

Ruostepuron osavaluma-alueen seurantaojissa virtaama oli suurimmillaan kevätsulamisen aikana, ja kevään virtaamahuippu oli voimakas ja kestoltaan vain noin kolme viikkoa (Kuva 4). Sulannan aikainen virtaamahuippu muodosti vuoden virtaamasta yli $60 \%$ peltovaltaisissa seurantapisteissä ja yli 50 $\%$ metsävaltaisessa pisteessä, minkä takia kevätsulamisen aikaan tuleva fosforikuorma oli syyssateiden aikaan tulevaa fosforikuormaa suurempi. Suomessa valunta on tyypillisesti suurimmillaan syyssateiden ja keväällä lumen sulamisen aikaan, ja siten valtaosa maatalouden aiheuttamasta fosforikuormituksesta ajoittuukin näihin kasvukauden ulkopuolella esiintyviin suuriin ja lyhytaikaisiin valumahuippuihin (Rekolainen 1992, Puustinen ym. 2007). Valkama ym. (2008) ovat osoittaneet, että pienissä virtavesissä muutokset virtaamissa ja veden laadussa ovat hyvinkin nopeita. Luotettavan kuormitusarvion saamiseksi näytteitä tulisi tulvajakson aikana ottaa useita päivässä ja tarvittaessa usean päivän ajan. Ensimmäisen seurantavuoden käytettävissä olevien tulosten perusteella näytteenottoa Kirmanjärvellä tullaan tarkentamaan ja tarkastelemaan myös pitoisuuksissa esiintyvän vuorokausivaihtelun merkitystä kuormituksen arvioinnissa etenkin kevät- ja syystulvien aikana. 


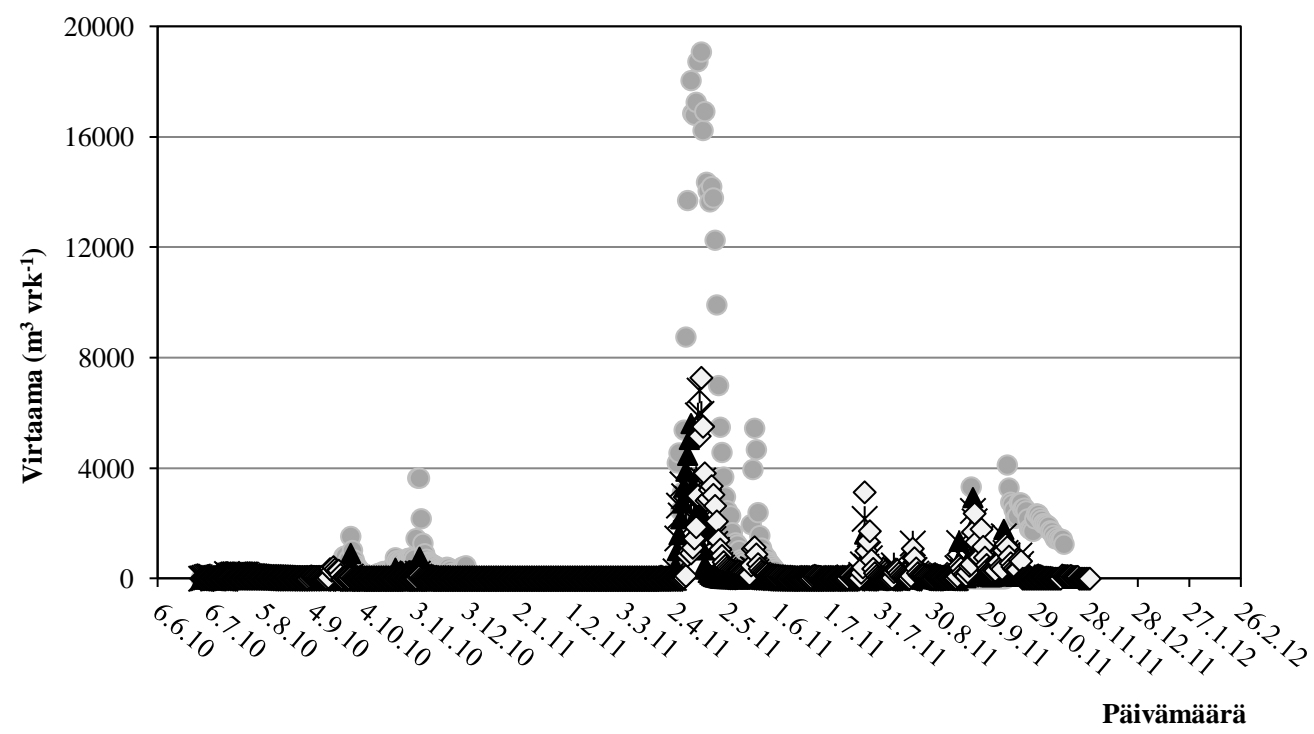

- Piste 1: Kirmanjärveen laskevassa Ruostepurossa oleva mittauspiste

Päivämäärä

$\Delta$ Piste 3: Peltovaltainen (pelto-\% 100) seuranta-alue

* Piste 4: Pelto- ja metsävaltainen (pelto-\% 50, metsä-\% 50) seuranta-alue

$\diamond$ Piste 5: Metsävaltainen seuranta-alue (metsä-\% lähes 100)

Kuva 4. Virtaama $\left(\mathrm{m}^{3} \mathrm{vrk}^{-1}\right)$ neljässä eri mittauspisteessä syksy-10 - syksy-11.

Pieniltä peltovaltaisilta valuma-alueilta on Suomessa arvioitu huuhtoutuvan fosforia $0,9-1,8 \mathrm{~kg}$ pelto$\mathrm{ha}^{-1} \mathrm{v}^{-1}$ tarkastelujaksolla 1981-1985 (Rekolainen 1989) ja 0,8-1,7 kg pelto-ha ${ }^{-1} \mathrm{v}^{-1}$ tarkastelujaksolla 1986-1990 (Rekolainen ym. 1995). Vuorenmaa ym. (2002) arvioivat pelloilta vesistöihin huuhtoutuvan kokonaisfosforikuormituksen olevan $1,1 \mathrm{~kg} \mathrm{ha}^{-1} \mathrm{v}^{-1}$ (tästä on vähennetty luonnon taustahuuhtouma). Luonnontilaisille kivennäismaille ja soille huuhtouma-arviot ovat huomattavasti peltomaille esitettyjä pienempiä, keskimäärin $0,049 \mathrm{~kg} \mathrm{ha}^{-1} \mathrm{v}^{-1}\left(0,017-0,146 \mathrm{~kg} \mathrm{ha}^{-1} \mathrm{v}^{-1}\right)$ (Finér ym. 2010). Vuoden 2011 alustavien tulosten perusteella Kirmanjärveen laskevasta Ruostepurosta valuma-alueen pintaalayksikköä kohti laskettu kokonaisfosforihuuhtouma jää peltovaltaisille alueille esitettyjä ominaiskuormitusarvioita pienemmäksi $\left(<0,4 \mathrm{~kg} \mathrm{ha}^{-1} \mathrm{v}^{-1}\right)$, kun taas metsävaltaisella seuranta-alueella fosforihuuhtouma on todennäköisesti muusta kuin maa- ja metsätalouden aiheuttamasta kuormituksesta johtuen esitettyjä arvioita suurempi (noin $0,3 \mathrm{~kg} \mathrm{ha}^{-1} \mathrm{v}^{-1}$ ). Pienelle peltovaltaiselle (pelto-\% 100) seurantakohteelle laskettu ominaiskuormitusarvio vastaa kirjallisuudessa esitettyjä arvioita. Fosforikuormituksen kannalta merkittävin tekijä on hydrologinen vuosivaihtelu (Puustinen ym. 2007). Hydrologisesti epäedullisina vuosina olosuhteiden vaikutus etenkin kiintoaineksen ja partikulaarisen fosforin kuormitukseen on hyvin suuri. Sen sijaan vaikutukset liukoiseen fosforiin jäävät pienemmiksi.

\section{Johtopäätökset}

Alustavat tulokset eivät osoita nautakarjatiloilta tulevan fosforikuormituksen olevan poikkeuksellisen suurta. Tulokset ovat kuitenkin vasta yhden vuoden ajalta ja nurmiviljelyn aiheuttaman fosforikuormituksen luotettava arviointi edellyttääkin riittävää näytteenottotiheyttä ja monivuotista seurantatutkimusta. Luotettavan kuormitusarvion saamiseksi ensimmäisen seurantavuoden käytettävissä olevien tulosten ja kokemusten perusteella näytteenottoa ja ravinnekuormituksen seurantaa tullaan myös tarkentamaan.

\section{Kiitokset}

Tätä tutkimusta ovat rahoittaneet MTT, MMM ja OLVI-säätiö.

\section{Kirjallisuus}

Ekholm, P., Granlund, K., Kauppila, P., Mitikka, S., Niemi, J., Rankinen, K., Räike, A. \& Räsänen, J. 2007. Influence of EU policy on agricultural nutrient losses and the state of receiving surface waters in Finland. Agricultural and Food Science 16: 282-300. 
Chang, S. C. \& Jackson, M. L. 1957. Fractionation of soil phosphorus. Soil Science 84: 133-144.

Finér, L., Mattsson, T., Joensuu, S., Koivusalo, H., Laurén, A., Makkonen, T., Nieminen, M., Tattari, S., Ahti, E., Kortelainen, P., Koskiaho, J., Leinonen, A., Nevalainen, R., Piirainen, S., Saarelainen, J. Sarkkola, S. \& Vuollekoski, M. 2010. Metsäisten valuma-alueiden vesistökuormituksen laskenta. Suomen ympäristö 10. Suomen ympäristökeskus. Helsinki. $33 \mathrm{~s}$.

Hartikainen, H. 1979. Phosphorus and its reactions in terrestrial soils and lake sediments. Journal of the Scientific Agricultural Society of Finland 51: 537-624.

Kaila, A. 1964. Fractions of inorganic phosphorus in Finnish mineral soils. The Journal of the Scientific Agricultural Society of Finland 36: 1-13.

Kauppinen, E. 2006. Kirmanjärven fosforitaseet ja kunnostuksen pääpiirteet vuodelle 2006. Vesi-Eko Oy Water-Eco Ltd. 79 s.

MMM Tike 2007. Maatilatilastollinen vuosikirja 2007.

Pohjois-Savon ELY-keskus. 2010. Pohjois-Savon vesienhoidon toimenpideohjelma vuosille 2010-2015. Pohjois-Savon elinkeino-, liikenne- ja ympäristökeskuksen julkaisuja 01/2010. $225 \mathrm{~s}$.

Puustinen, M., Tattari, S., Koskiaho, J. \& Linjama, J. 2007. Influence of seasonal and annual hydrological variations on erosion and phosphorus transport from arable areas in Finland. Soil \& Tillage Research 93: 44-55. Rekolainen, S. 1989. Phosphorus and nitrogen load from forest and agricultural areas in Finland. Aqua Fennica 19: 95-107.

Rekolainen, S. 1992. Maatalouden aiheuttama fosfori- ja typpikuorma vesistöihin. Julkaisussa: Rekolainen, S. \& Kauppi, L. (toim.). Maatalous- ja vesien kuormitus. Yhteistutkimusprojektin tutkimusraportit. Vesi- ja ympäristöhallituksen monistesarja 359. Vesi- ja ympäristöhallitus, Helsinki. s. 9-15. 206 s.

Rekolainen, S., Pitkänen, H., Bleeker, A. \& Sietske, F. 1995. Nitrogen and phosphorus fluxes from Finnish agricultural areas to the Baltic Sea. Nordic Hydrology 26: 55-72.

Saarela, I. \& Vuorinen, M. 2009. Stratification of soil phosphorus, pH and macro cations under intensively cropped grass ley. Nutrient Cycling in Agroecosystems 86: 367-381.

Saarijärvi, K., Karppinen, M., Uusi-Kämppä, J., Turtola, E. \& Virkajärvi, P. 2006. Laitumen fosforitalous ja vesistökuormituksen hallinta. Julkaisussa: Alakukku, L. (toim.) . Maaperän prosessit - pellon kunnon ja ympäristönhoidon perusta. MMM:n maaperätutkimusohjelman loppuraportti. Maa- ja elintarviketalous 82. s 23-32. $128 \mathrm{~s}$.

Sharpley, A.N. 1995. Dependence of runoff phosphorus on extractable soil phosphorus. Journal of Environmental Quality 24: 920-926.

Siimekselä, T., Stenman, T. \& Ylimartimo, A. 2011. Tuloksia pilottikokeesta pienellä valuma-alueella Saarijärven vesireitin varrella. Vesitalous 6: 24-28.

Turtola, E. \& Kemppainen, E. 1998. Nitrogen and phosphorus losses in surface runoff and drainage water after application of slurry and mineral fertilizer to perennial grass ley. Agricultural and Food Science in Finland 7: 569-581.

Turtola, E. \& Yli-Halla, M. 1999. Fate of phosphorus applied in slurry and mineral fertilizer: accumulation in soil and release into surface runoff water. Nutrient Cycling in Agroecosystems 55: 165-174.

Valkama. P., Lahti, K. \& Särkelä, A. 2008. Jatkuvatoiminen veden laadun seuranta hajakuormituksen arvioinnissa. Julkaisussa: Hopponen, A. (toim.). Maataloustieteen Päivät 2008 (verkkojulkaisu). Suomen Maataloustieteellisen Seuran tiedotteita no 23. http://www.smts.fi/mpol2008/index tiedostot/Posterit/ps036.pdf. Viitattu 8.12.11.

Vuorenmaa, J., Rekolainen, S., Lepistö, A., Kenttämies, K. \& Kauppila, P. 2002. Losses of nitrogen and phosphorus from agricultural and forest areas in Finland during the 1980s and 1990s. Environmental Monitoring and Assessment 76: 213-248.

Vuorinen J. \& Mäkitie, O. 1955. The method of soil testing in use in Finland. Agrogeological Publications 63:1-44. 